Article

\title{
Development of Environmentally Sustainable Methods for Treatment of Domestic Wastewater and Handling of Sewage Sludge on Yap Island
}

\author{
Joseph D. Rouse \\ Water and Environmental Research Institute of the Western Pacific, University of Guam, \\ UOG Station, Mangilao 96923, Guam; E-Mail: rousej@triton.uog.edu; Tel.: +1-671-735-2691; \\ Fax: +1-671-734-8890
}

Academic Editor: Marc A. Rosen

Received: 30 April 2015 / Accepted: 4 September 2015 / Published: 11 September 2015

\begin{abstract}
A survey was conducted of the wastewater treatment systems and related sludge handling practices on the island of Yap, in the Federated States of Micronesia, to assist in identifying areas where further work would be merited to improve on effectiveness and sustainability. A detailed inventory was made of communal septic tanks as found at health centers and schools. Though most of these septic tanks appeared to be functional, there were concerns due to some units being positioned within the tidal zone, covered over with vegetation, or out of reach of the pump truck. Furthermore, the centralized wastewater treatment plant on Yap provides only primary treatment consisting of a limited removal of suspended solids. Thus, only partially treated sewage is being discharged to the bay. Excess sludge is drawn from the treatment plant on a quarterly basis, which local farmers regularly make use of as fertilizer for crop application without adequate treatment. As an immediate target for further study and pilot testing, exploring the use of an attached-growth process as an inexpensive retrofit to enhance the effectiveness of the treatment plant is proposed. In addition, the benefits of implementing a composting program for recycle of waste sludge in a safe manner and developing a framework for management of septic tanks are discussed.
\end{abstract}

Keywords: wastewater; sewage sludge; treatment; sustainable infrastructure; tropical islands; Yap; Micronesia 


\section{Introduction}

Inadequate treatment of domestic wastewater (or sewage) in the islands of the Western Pacific has been responsible for serious human and environmental health problems due to contamination of water supplies and damage to natural resources [1]. The reason for this has often been attributed to the lack of functional technologies, which are difficult to obtain and maintain due to the vast geographical distances among the island communities and the high costs for providing services.

Yap State (Figure 1), the western-most state of the Federated States of Micronesia (FSM), covers approximately 500,000 square miles (1,300,000 square kilometers) of ocean yet has only 45.8 square miles (119 square kilometers) of land surface, consisting of numerous small islands. Only about 20 of these are inhabited. The main island of Yap (Figure 2), traditionally called "Wa'ab," is actually four closely interconnected continental islands with a population of approximately 7700 people, or $65 \%$ of the state population (estimated to be 11,863 persons in 2015 [2]) [3]. The only centralized wastewater treatment plant (WWTP) in the state is in the town of Colonia on the island of Yap [4]. The treatment currently being provided, though, is clearly insufficient, with only primary treatment being applied prior to discharging to the ocean near the population center. In addition, the number and locations of pit latrines and septic tanks on the island are not adequately inventoried and the degree of treatment and extent of upkeep being provided are largely unknown. Furthermore, excess sludge produced at the WWTP is used for agricultural purposes without prior treatment to meet appropriate standards for human safety. Thus, improved management of this potentially useful resource is urgently needed.

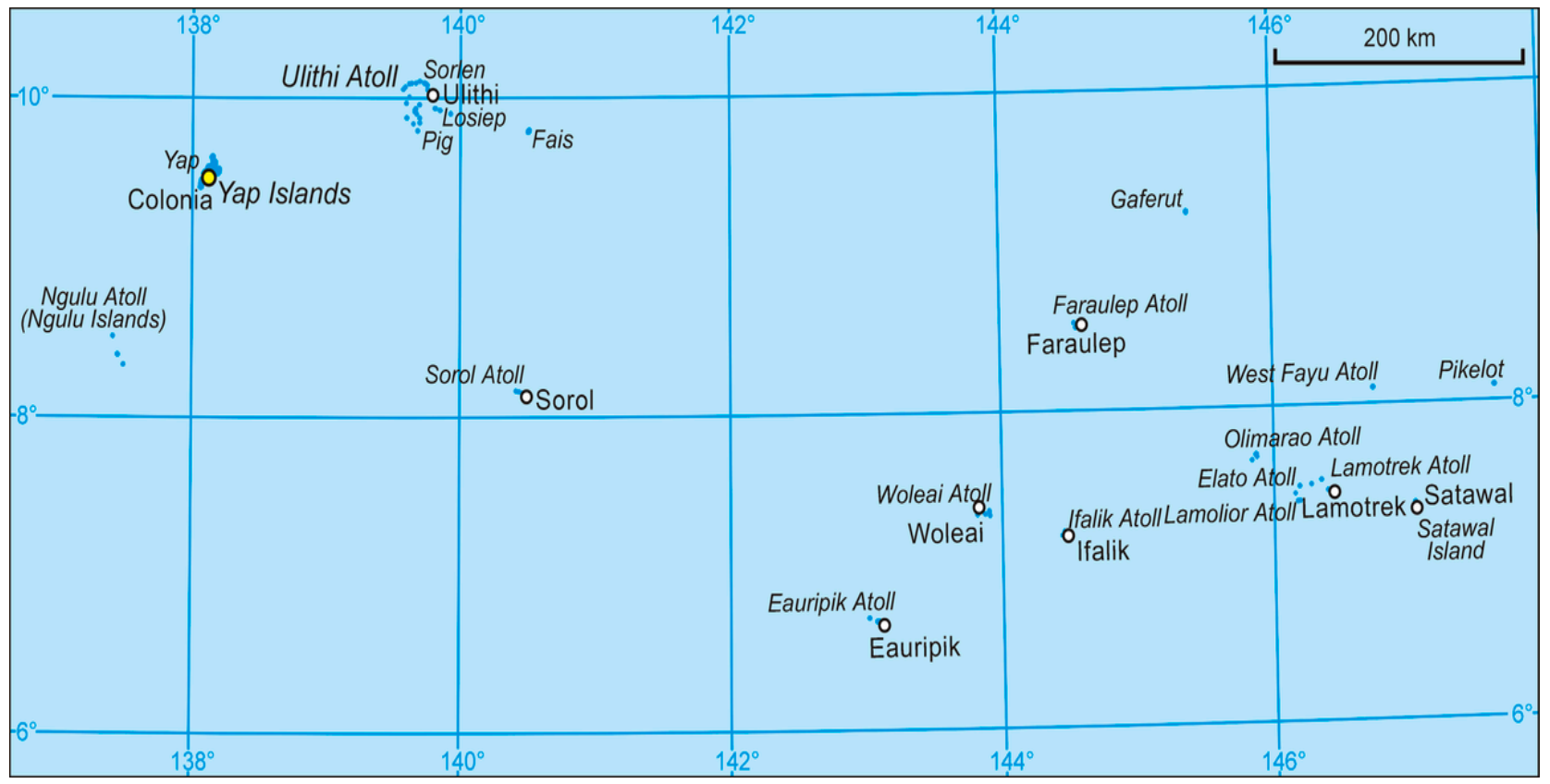

Figure 1. Map showing the island of Yap (upper-left corner) among the islands of Yap State of the Federated States of Micronesia. Image source: Aotearoa—Wikimedia Commons [5].

The objective of this project is to perform an inventory on the existing wastewater treatment methods on the island of Yap. This objective was met by conducting field surveys to document and characterize the existing wastewater treatment systems and related sludge handling practices on Yap. As practicable, these items are to include: 
(a) Identification of locations of individual treatment units (i.e., pit latrines and septic tanks) and evaluation of condition.

(b) Description of the centralized wastewater treatment plant, including design capacity and degree of treatment being achieved.

(c) Description of excess sludge handling practices, including the quantity of sludge generated and degree of treatment being achieved.

(d) Documentation of disposal practices for treated wastewater and excess sludge and evaluation of environmental and public health impacts.

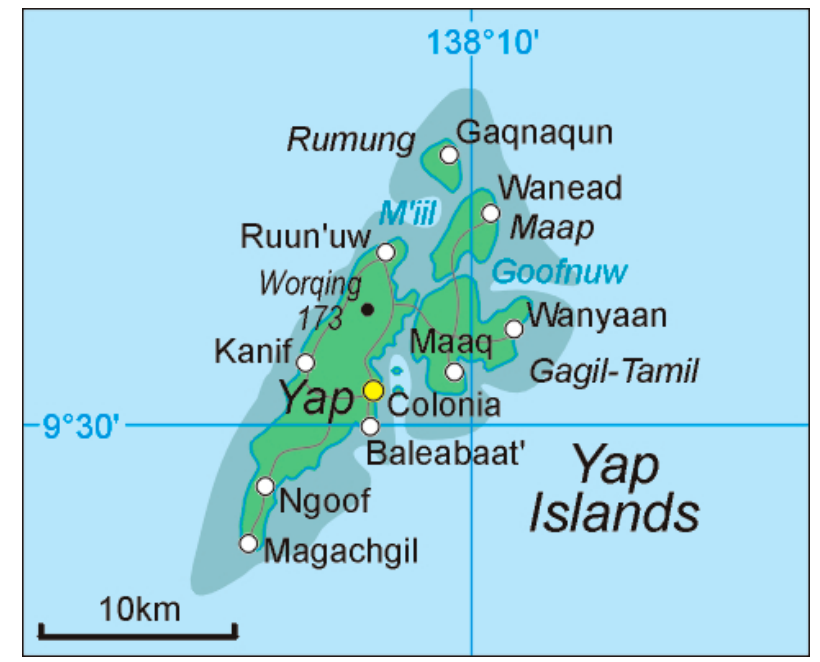

Figure 2. Map showing the main island system of Yap, of Yap State, consisting of four interconnected islands. Image source: Aotearoa-Wikimedia Commons [5].

\section{Methods}

The methods employed over the course of this project incorporated civil and environmental engineering fieldwork. Prior to commencing fieldwork, points of contact in the Yap Environmental Protection Agency (Yap EPA) and utilities offices were established to clarify the intent of the investigation to the local authorities.

Fieldwork commenced by conducting meetings with pertinent local officials on utility boards and other government agencies to obtain guidance concerning locations and details of septic tanks and other wastewater treatment facilities. Subsequently, as practicable, the locations of these facilities were confirmed and documented by use of global positioning system (GPS) technology (Colorado 300, Garmin). Furthermore, the sole wastewater treatment plant and related disposal practices were inspected and documented.

\section{Principal Findings and Discussion}

\subsection{Septic Tanks}

Septic tanks are reportedly being used as a first line of treatment for domestic wastewater at $31 \%$ of the 2311 households in Yap State [6], where a household on average consists of six persons. Almost all of these septic tanks - as concrete box structures - are located on the main island of Yap. 
It was not practicable, nor considered advisable, to attempt to locate and inspect all the household septic tanks, which amounts to an estimated 700 units - all located on private property. The Yap EPA does not have a full accounting of the numbers and locations of septic tanks because to date there have been no enforceable regulations concerning their construction and placement. Registration of septic tanks only occurs when a loan or grant is involved, as with the construction or purchase of a house, and over a recent four-year period only 18 units have been formally noted in the agency's Septic Tank System Log. However, the Loan and Grant Division of the Yap Community Action Program has design drawings for use in new construction of single compartment septic tanks. The design consists of a 4- by 5 -ft $(1.2$ by $1.5 \mathrm{~m})$ reinforced concrete tank with a 6 -ft $(1.8 \mathrm{~m})$ depth and two parallel $20-\mathrm{ft}$ $(6.1 \mathrm{~m})$ leaching lines. It is doubtful, though, that many (if any) of the existing residential units employ a leaching field, versus a leaching pit. The septic tanks discharge to the subsurface, potentially affecting groundwater resources; accordingly, the enhanced natural attenuation offered by a properly designed leaching field would be a valuable safety factor.

The Yap State Public Service Corporation responds to about three service calls per month to pump out septic tanks, which they provide for a fee of $\$ 90$ per tank. About once every year they encounter difficulties such as a septic tank being in an inaccessible location or not having an access port (manhole) built into the concrete structure. Overall, there are no outstanding problems with the use of septic tanks on the island that would call for immediate corrective action. However, the impact of septic tank discharges on the quality of groundwater, and possibly even coastal ocean water, could be difficult to discern apart from a well-directed sampling program, or an outbreak of illness.

With the assistance of the Yap EPA, it was considered reasonable to conduct a thorough inventory of communal septic tanks (Figure 3), such as those found at Community Health Centers (Table 1), Early Childhood Education Centers (Table 2), Elementary Schools (Table 3), and other miscellaneous facilities (Table 4). The general condition and functionality of each unit was documented and their precise locations determined by GPS. The GPS data, however, are not repeated in this report, but are made available separately for use by appropriate authorities.

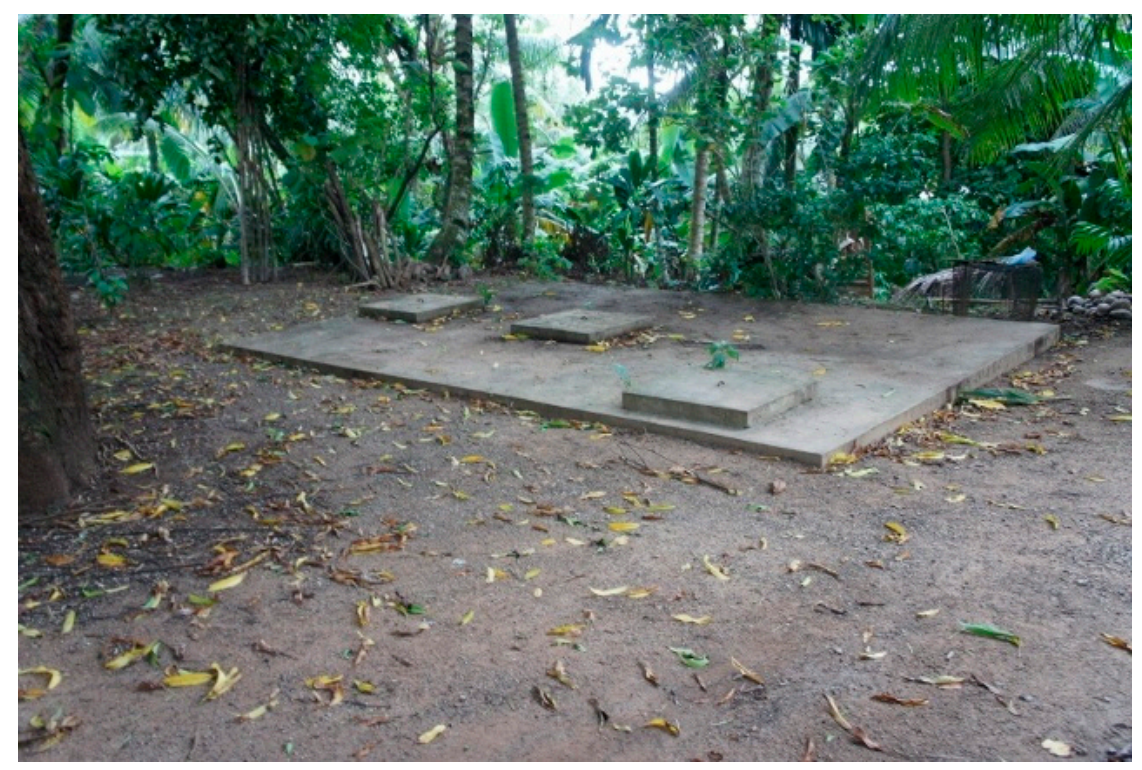

Figure 3. Large communal septic tank used in remotely located Daabach Village on Yap. Image source: author. 
Table 1. Septic Tanks (STs) at Community Health Centers.

\begin{tabular}{ccc}
\hline & Village/Area & Comments \\
\hline 1 & Maap/Rumuung & ST appears functional \\
2 & Gagil & ST appears functional \\
3 & Tomil & ST appears functional \\
4 & Malaav & ST appears functional \\
5 & Gilman & ST appears functional \\
\hline
\end{tabular}

Table 2. Septic Tanks (STs) at Early Childhood Education Centers.

\begin{tabular}{ccc}
\hline & Village/Area & Comments \\
\hline 1 & Maap & ST appears functional \\
2 & Rumuu & ST in ocean tidal zone \\
3 & Gagil & ST appears functional \\
4 & Tomil & ST appears functional \\
5 & Dalipeebinaew & ST covered by vegetation \\
6 & Kanifay & ST appears functional \\
7 & Gilman & ST appears functional \\
\hline
\end{tabular}

Table 3. Septic Tanks (STs) at Elementary Schools.

\begin{tabular}{ccc}
\hline & Village/Area & Comments \\
\hline 1 & Maap/Tamilaeng & Out of reach of pump truck \\
2 & North Fanif & ST appears functional \\
3 & SDA Campus & Seven functional STs \\
4 & Rumuu & ST under outhouse \\
5 & Bael & ST appears functional \\
6 & Gagil & Holding tank only, no drainage \\
7 & Tomil (B) & ST appears functional \\
8 & Tomil (A) & ST appears functional \\
9 & Dalipeedinaew & ST appears functional \\
10 & Kanifay & ST covered by vegetation \\
11 & Gilman & ST exact location not confirmable \\
\hline
\end{tabular}

Table 4. Septic Tanks (STs) at other communal locations.

\begin{tabular}{ccc}
\hline & Village/area & Comments \\
\hline 1 & Ablul Village & Two STs for village outhouses \\
2 & Maritime Academy & STs not confirmed (out of scope) \\
3 & Daabach Village & Large septic tank for village \\
4 & Catholic High School & Large retrofitted ST \\
\hline
\end{tabular}

As noted in the Tables 1-4, many of the communal septic tanks appeared to be fully functional and a duty manager with knowledge of the system was often present who could attest to periodic servicing. There were some concerns, though, such as the septic tank at Rumuu Early Childhood Education Center (Table 2), which is positioned in the tidal zone and encroached by seawater. In addition, there were two tanks covered with vegetation (Tables 2 and 3), and one case were the location of the tank could not be 
visually confirmed (Gilman Elementary School, Table 3). In those cases it is doubtful whether the tanks are being properly maintained. Furthermore, at Maap/Tamilaeng Elementary School (Table 3) the septic tank was located down a steep slope in a forest growth and was out of reach of the pump truck. This septic tank was overloaded and extremely foul and no doubt will have to be abandoned in favor of a more suitable location in due time.

At the time of this report, an environmental lawyer was on a two-year assignment with the Yap EPA to develop environmental regulations that will, in part, cover the construction, placement, and operation of septic tanks and leaching fields. These regulations should start having positive environmental impacts in the not too distant future. Though not binding in the FSM, the Guam EPA has requirements for placing septic tanks and leaching fields that vary according to the geological features in different parts of the island. Yap likewise needs to determine the proper management of septic tanks with respect to the local environmental conditions. In the Philippines a National Sewerage and Septage Management Program was recently established to improve sanitation through a combined approach to septic tank cleaning and fecal sludge management [7]. The program employs a holistic approach offering advice on such issues as tariffs and fees, cleaning frequency of tanks, and methods to gain public participation. Early results have shown that there is no single right way to implement such a program and that adaptation to local circumstances is critical to success. Lessons being learned and best management practices are being developed, which may also be of interest on Yap and other tropical-island communities.

\subsection{Landfill Leachate}

Following in suit with the Fukuoka-type landfill installed in Kosrae, FSM, a few years ago [6], Yap State has also chosen to construct the same type of landfill (nearly completed at the time of this study; Figure 4). While a landfill leachate collection and treatment system would be more appropriately classified as an industrial operation, due to this landfill being predominately for domestic solid waste, it will be briefly discussed in this report concerned with domestic wastewater. The uniqueness of the Fukuoka-type landfill is that ventilation is employed to promote aerated conditions throughout the landfill with the intent of preventing methane production, which requires anaerobic conditions. Considering that methane gas production at landfills is generally not rich enough to be used as an energy source, it is deemed more suitable to avoid its production and thus reduce the potential of methane escaping to the atmosphere. The reported effects of methane as a greenhouse gas are much greater than that of carbon dioxide [8], which is the normal off-gas component under aerobic conditions.

The leachate pond shown in Figure 5 was holding only rainwater at the time of this report (prior to commencement of trash collection). Overflow from this pond passes through a sand filter (Figure 6) prior to being discharged to a forest gully. Effluent discharged from this new facility on Yap will be analyzed for chemical oxidation demand (COD) and $\mathrm{pH}$ (Standards promulgated in Kosrae call for COD levels to be maintained below $100 \mathrm{mg} / \mathrm{L}$ and $\mathrm{pH}$ below 10, which have reportedly been successfully met due to diligent segregation of waste materials prior to deposition [6]). For Yap, a more aggressive form of leachate treatment may have to be considered if discharge standards to be established in the future cannot be maintained. 


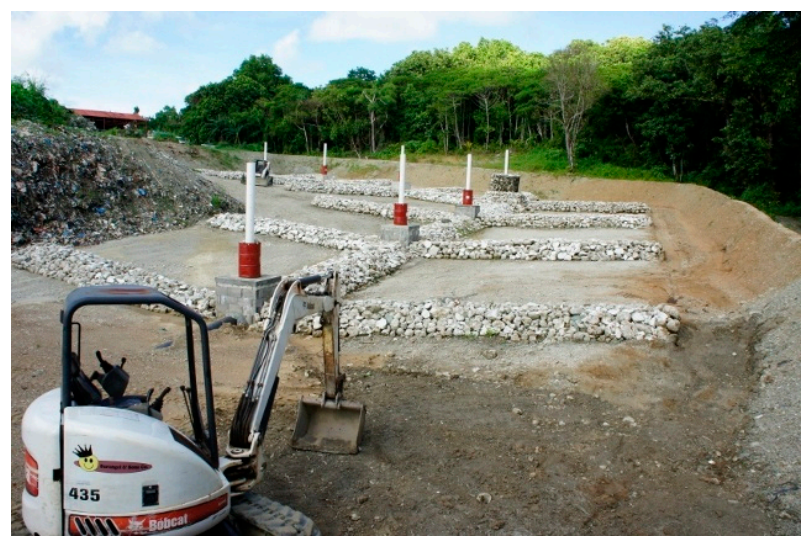

Figure 4. Newly constructed Fukuoka-type landfill on Yap prior to first use. Image source: author.

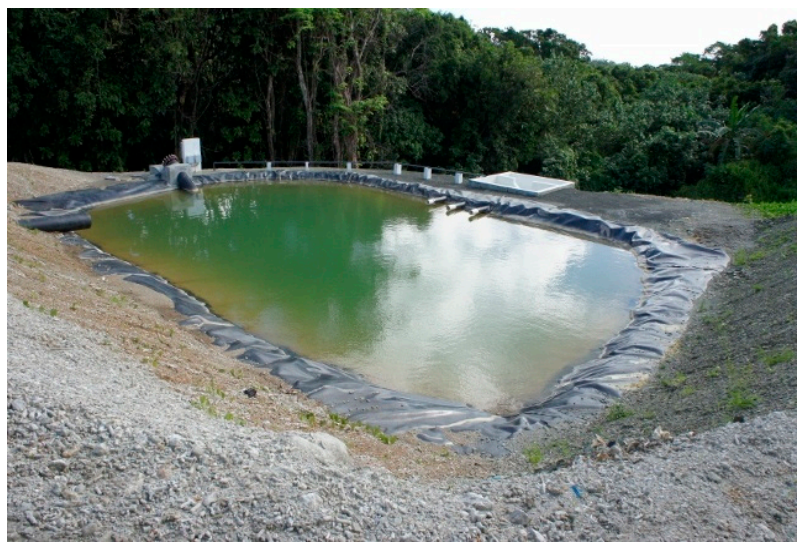

Figure 5. Leachate collection pond at the new landfill. White box on far side of pond is the sand filtration unit. Image source: author.

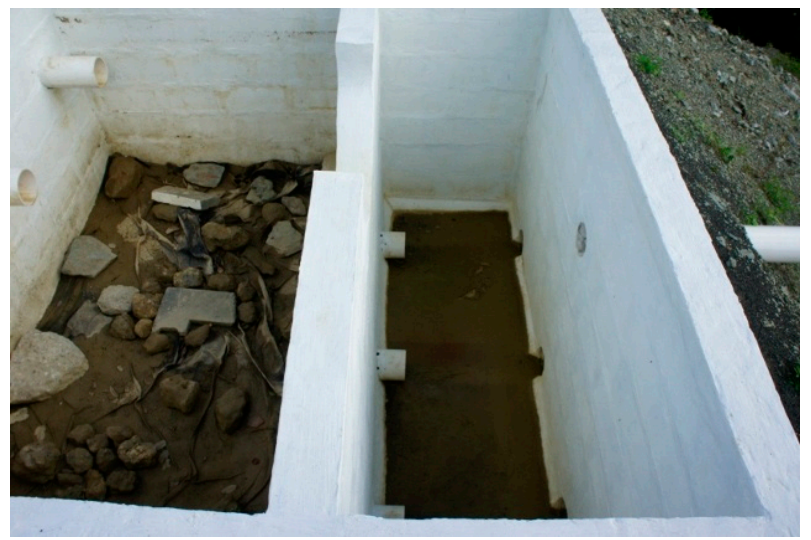

Figure 6. Detailed view of the sand filtration unit process at the new landfill. Image source: author.

\subsection{Wastewater Treatment}

The municipal WWTP in Colonia (Figure 7), serving the main residential area and business center on Yap, was commissioned around 1974. The plant consists of an Imhoff tank system with two lines designed to operate in parallel (Figure 8); however, only one line is used at a time due to the relatively low intermittent flow entering the plant from only about 300 household connections. The unmetered inflow is thought to be somewhat less than the design flow of 170,000 gal/day $\left(640 \mathrm{~m}^{3} /\right.$ day $)$. Imhoff 
tanks are very user friendly and have low operational costs due to the absence of aeration and internal recycle. According to the operational manual of the plant, the system was designed for removal of $25 \%$ of the biochemical oxygen demand and $60 \%$ of the suspended solids from the raw wastewater. There are no records, though, of any data ever being collected and there is no on-island capability for conducting such analyses. The solids that settle in a compartment below the flow channel are subject to some degree of anaerobic digestion depending on the retention time. These solids are periodically expelled under the natural hydraulic head in the system, thus eliminating the need for mechanical pumping. No chemical or other biological treatment is employed in the plant, hence the effluent, which is being discharged to the ocean, is not much different from raw sewage. Furthermore, the 1000-ft $(300 \mathrm{~m})$ outfall is known to be broken open at approximately $500 \mathrm{ft}(150 \mathrm{~m})$ from the shore. As a consequence, it is discharging sewage at a depth of 10 to $20 \mathrm{ft}$ ( 3 to $6 \mathrm{~m}$ ) near the industrial district of Colonia about half a mile (one kilometer) from the main business district. However, testing by the Yap EPA in the coastal zone has yet to yield a count of greater than 30 Enterococci per 100 milliliters of sea water, which would be considered a potential danger to public health.

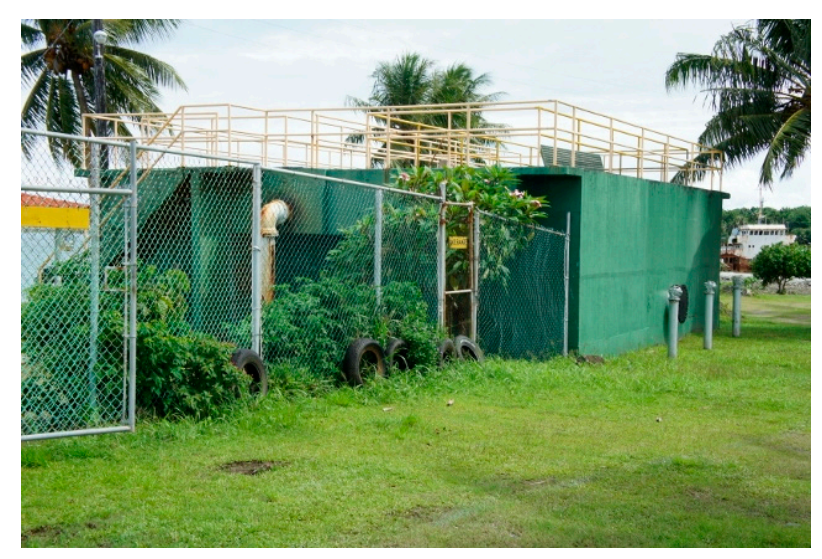

Figure 7. Imhoff tank sewage treatment plant in Colonia, Yap. Image source: author.

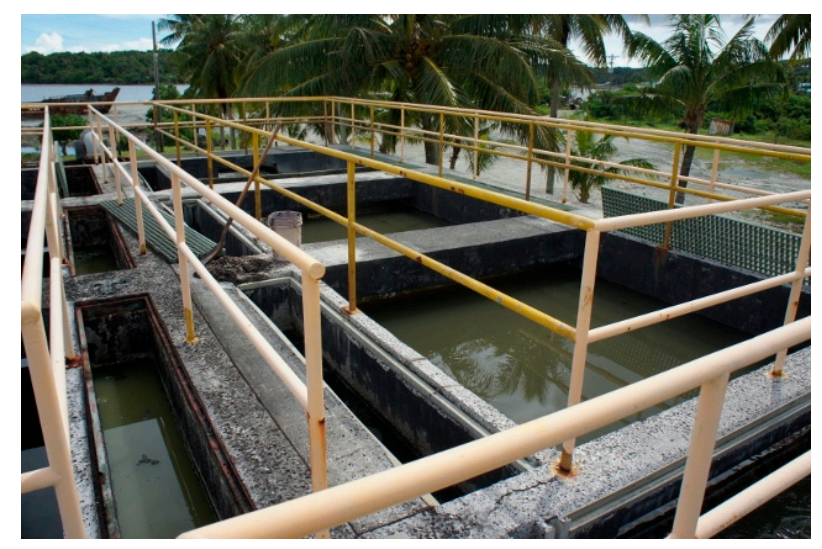

Figure 8. One flow line in the Imhoff tank sewage treatment plant. Image source: author.

To upgrade the process to a conventional activated-sludge based secondary level of treatment, a completely new plant would have to be constructed with a larger footprint including space for a clarifier unit process. Such a facility would require substantial capital and operation and maintenance costs. Another method worthy of consideration that could harness biological treatment power with 
a relatively simple addition to the existing facility would be to use an attached-growth (or biofilm) process $[9,10]$. Using this method, effective biomass could be retained in the unit process by use of a biocarrier support matrix. Potentially, as a relatively simple retrofit, biocarrier material could be attached to a frame and positioned in the existing tank so as to intercept the flow path of the wastewater. Figure 9 shows the interior of one of the Imhoff tanks drained for inspection, where such a frame could be inserted. Evaluation of such an attached-growth process would be an avenue for future research and development.

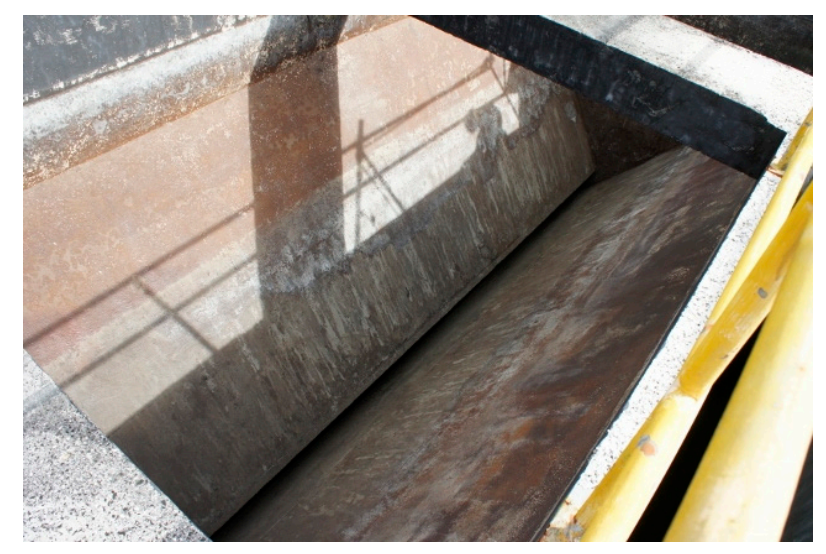

Figure 9. Imhoff tank emptied for inspection showing compartment where biocarrier matrix could be inserted. Image source: author.

\subsection{Sludge Handling}

Approximately four times a year, partially digested excess sludge is drawn from the bottom of the Imhoff tanks (Figures 10 and 11). It is intended that following drying (Figure 12) the sludge would be disposed of at the solid waste landfill; however, before this can be done local farmers take it to be used as fertilizer for food crops, despite the potential risk to human health [11]. Currently, there is no regulatory guidance in Yap State concerning treatment requirements for sewage sludge prior to use. Though not binding in the FSM, the United States EPA offers widely accepted definitions for different classes of biosolids that could serve as a guideline [12]. Exceptional quality (Class A) biosolids, which have no crop harvesting restrictions, consist of treated residuals that contain no detectible levels of pathogens and low levels of heavy metals [12]. Technologies that can meet Class A standards must be able to yield a product in keeping with the required pathogen cut. Composting is one such option that can be considered as an environmentally friendly method to recycle the nutrients and organic matter found in municipal wastewater solids. If Class A treatment is achieved, the cured compost could be used for production of food crops; or if the level of treatment is inferior, the product could still possibly be used for environmental reparation of badlands, which are in abundance on Yap.

Composting is a biologically active process where the conditions must be met to maintain an aerobic (aerated) environment. This requires keeping the moisture content around 50\% to promote transport of nutrients throughout the pile while allowing enough void space for adequate ventilation [13]. Mixing materials with different textures into the pile would contribute to success, which can be achieved by adding yard waste with the sludge and turning (mixing) the pile occasionally (about twice a week) [13]. Coupled with an industrial grade thermometer to monitor the temperature in the pile, standardized 
procedures should be obtainable (i.e., 30 days active composting with internal temperatures of $55{ }^{\circ} \mathrm{C}$ $\left(130^{\circ} \mathrm{F}\right)$ or higher for 15 days [14]). By this, the final product can be reasonable assumed to meet Class A standards, though further consideration should be given to levels of heavy metals and vector attraction reduction [12].

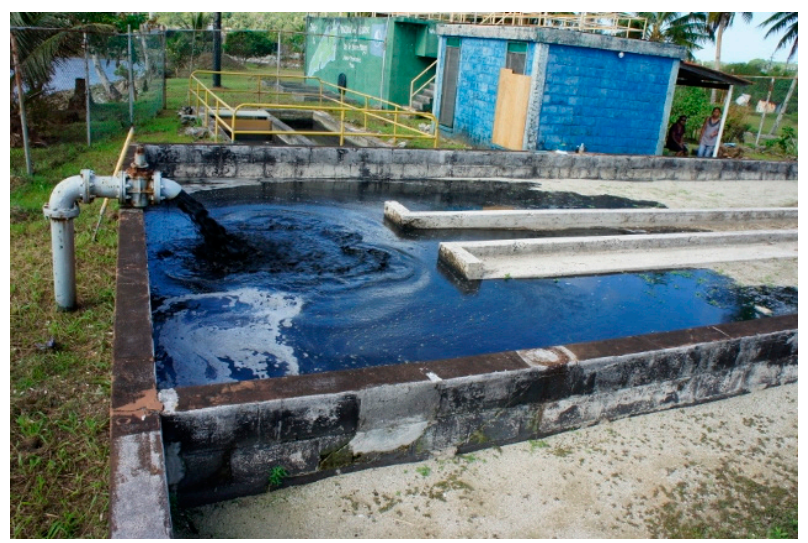

Figure 10. Sewage sludge from Imhoff tank being discharged to drying bed. Image source: author.

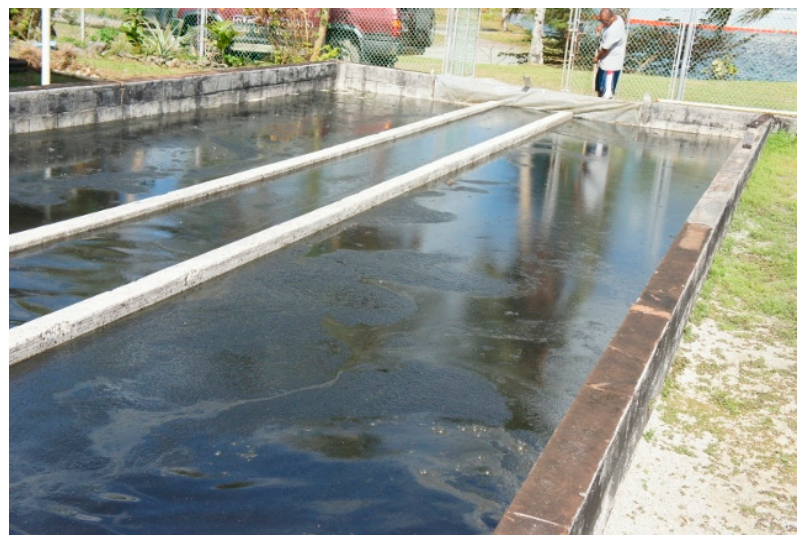

Figure 11. Fresh wet sewage sludge in drying bed at beginning of drying period. Image source: author.

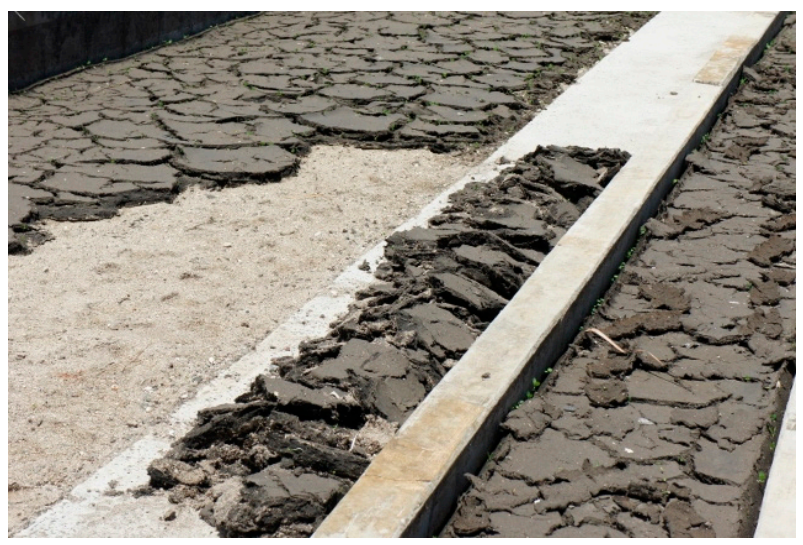

Figure 12. Air dried sludge with an estimated 50\% solids content. Image source: author.

Rigorous bacteriological testing should be used to evaluate the compost product prior to use. However, if any questions concerning safety should emerge due to a lack of testing, applications avoiding contact with food crops could readily be employed. Public perception on the use of treated 
sludge products represents an important factor when confronted with options for application. Despite overall improvements to the quality of biosolids in recent years due to research on treatment methods and advances in monitoring techniques, concerns over public health are not misplaced and should be openly incorporated into the decision making process [15].

As the subject of a subsequent study, a pilot test could be conducted to evaluate the feasibility of developing a suitable composting practice at the WWTP. A rough estimate of the quantity of air dried excess sludge ( $\mathrm{ca} .50 \%$ solids) per sludge drawing event (about four times per year) comes to only $100 \mathrm{ft}^{3}\left(3 \mathrm{~m}^{3}\right)$, which should be a workable volume, not requiring the aid of motorized equipment. Notwithstanding, if a greatly expanded septic-tank sludge collection program were to be implemented (as discussed above), then a further study would be necessary to scale the facility and equipment accordingly. The potential benefits of composting would include:

(a) reducing solid waste input to the new landfill,

(b) protecting the public from health hazards,

(c) repairing badlands, and

(d) generating revenue.

\section{Conclusions}

It is evident from this study that considerable progress has been made on Yap to bring the status of domestic wastewater treatment and sludge handling practices to a reasonable level of development. However, conclusions drawn here also suggest that further work is merited to achieve a higher degree of treatment in a more sustainable manner. More specifically, developing a framework for the management of septic tanks and implementing a composting program for recycle of waste sludge would do much to enhance public safety and environmental sustainability. In addition, exploring the use of an attached-growth process as an inexpensive means of improving the efficiency of the WWTP, as opposed to constructing a conventional activated-sludge system with costly maintenance requirements, is discussed.

\section{Acknowledgments}

The author would like to thank the people of the Yap State Public Service Corporation and the Yap EPA for their professional assistance provided unreservedly during the fieldwork stage of this project. In addition, special thanks are extended to Mathew Thigthen of the Yap EPA for assistance in conducting field work and to William M.C. Whitman of the University of Guam for assistance in obtaining GPS (global positioning system) data.

\section{Conflicts of Interest}

The author declares no conflicts of interest.

\section{References}

1. Pacific Islands Applied Geoscience Commission. Pacific Wastewater Policy Statement. Available online: http://pacificwater.org/userfiles/file/water\%20publication/WastewaterPolicy.pdf (accessed on 28 July 2015). 
2. Office of Statistics. Budget and Economic Management, Overseas Development Assistance, and Compact Management (SBOC), Palikir, Pohnpei State, FSM. Available online: http://www.sboc.fm/ index.php?id1=Vm0xMF1WbFdWWGhUYmxKV11XczFVbFpyVWtKUFVUMDk (accessed on 28 July 2015).

3. Maskarinec, G.G.; Yalmadau, K.; Maluchmai, M.R.; MO, P.T.; Yinnifel, C.; Hancock, W.T. Palliative care and traditional practices of death and dying in Wa'ab (Yap proper) and in the outer islands of Yap. Hawaii Med. J. 2011, 70 (Suppl. S2), 27-30. Available online: http://www.ncbi.nlm.nih.gov/pmc/issues/204252/ (accessed on 28 July 2015).

4. Rouse, J.D. Development of environmentally Sustainable Methods for Treatment of Domestic Wastewater and Handling of Sewage Sludge on Yap Island. Available online: http://www.sciforum.net/conference/wsf-4/wsf-d (accessed on 28 July 2015).

5. Wikimedia Commons. Available online: http://commons.wikimedia.org/wiki/Category:Maps_of_Yap (accessed on 28 July 2015).

6. Rouse, J.D. Sustainability of wastewater treatment and excess sludge handling practices in the federated states of Micronesia. Sustainability 2013, 5, 4183-4194. Available online: http://www.mdpi.com/2071-1050/5/10 (accessed on 28 July 2015).

7. Robbins, D.; Strande, L.; Doczi, J. Sludge Management in Developing Countries; International Water Association: London, UK, 2012; pp. 22-25.

8. Schmidt, G.A. Methane: A Scientific Journey from Obscurity to Climate Super-Stardom; National Aeronautics and Space Administration Goddard Institute for Space Studies: New York, NY, USA, 2004. Available online: http:/www.giss.nasa.gov/research/features/200409_methane/ (accessed on 28 July 2015).

9. Rouse, J.D.; Yazaki, D.; Cheng, Y.; Koyama, T.; Furukawa, K. Swim-bed technology as an innovative attached-growth process for high-rate wastewater treatment. Jpn. J. Water Treat. Biol. 2004, 40, 115-124. Available online: https://www.jstage.jst.go.jp/browse/jswtb/40/3/_contents (accessed on 28 July 2015).

10. Rouse, J.D.; Yoshida, N.; Hatanaka, H.; Imajo, U.; Furukawa, K. Continuous treatment studies of anaerobic oxidation of ammonium using a nonwoven biomass carrier. Jpn. J. Water Treat. Biol. 2003, 39, 33-41. Available online: https://www.jstage.jst.go.jp/browse/jswtb/39/1/_contents (accessed on 28 July 2015).

11. University of Georgia. Researchers link increased risk of illness to sewage sludge used as fertilizer. Science Daily, 30 July 2002. Available online: http://www.sciencedaily.com/releases/ 2002/07/020730075144.htm (accessed on 28 July 2015).

12. U.S. Environmental Protection Agency. A Plain English Guide to the EPA Part 503 Biosolids Rule. Available online: http://water.epa.gov/scitech/wastetech/biosolids/503pe_index.cfm (accessed on 28 July 2015).

13. Bassan, M.; Dodane, P.-H.; Strande, L. Treatment mechanisms. In Faecal Sludge Management, Systems Approach for Implementation and Operation; Strande, L., Ronteltap, M., Brdjanovic, D., Eds.; IWA Publishing: London, UK, 2014; pp. 45-66. 
14. Benedict, A.H.; Epstein, E.; Alpert, J. Composting Municipal Sludge; Pollution Technology Review No. 152; Noyes Data Corp.: Park Ridge, NJ, USA, 1988; p. 177.

15. Guo, M. Disposal of biosolids through land application: Concerns and opportunities. Hydrol. Curr. Res. 2012, 3, e104. Available online: http://dx.doi.org/10.4172/2157-7587.1000e104 (accessed on 28 July 2015).

(C) 2015 by the authors; licensee MDPI, Basel, Switzerland. This article is an open access article distributed under the terms and conditions of the Creative Commons Attribution license (http://creativecommons.org/licenses/by/4.0/). 